\title{
THE FEEDING HABITS OF THE STRANGE CROCODYLIAN MOURASUCHUS (ALLIGATOROIDEA, CAIMANINAE): A REVIEW, NEW HYPOTHESES AND PERSPECTIVES
}

\author{
GIOVANNE M. CIDADE \\ Programa de Pós-Graduação em Biologia Comparada, Departamento de Biologia, FFCLRP, Universidade de São Paulo, \\ Avenida Bandeirantes, 3900, 14040-901, Ribeirão Preto, São Paulo, Brazil. \\ giovannecidade@hotmail.com \\ DOUGLAS RIFF \\ Instituto de Biologia, Universidade Federal de Uberlândia, Uberlândia, Minas Gerais, Brazil. Rua Ceará, s/n, 38400-902, \\ Uberlândia, Minas Gerais, Brazil. \\ driff2@gmail.com \\ ANNIE SCHMALTZ HSIOU \\ Departamento de Biologia, FFCLRP, Universidade de São Paulo; Avenida Bandeirantes, 3900, 14040-901, Ribeirão Preto, \\ São Paulo, Brazil. \\ anniehsiou@ffclrp.usp.br
}

\begin{abstract}
The caimanine crocodylian Mourasuchus from the Miocene of South America is one of the most peculiar crocodylomorphs of all time. It exhibits an unusual long, wide and dorsoventrally flattened rostrum, long, slender mandibles, and relatively short cervical vertebrae. These features have led previous authors to propose that the feeding habits of Mourasuchus were very different from those of most crocodylomorphs. In order to significantly improve the knowledge on the feeding habits of Mourasuchus, we performed a comprehensive review on this issue in order to offer the most complete assessment on the question to date, and to propose new hypotheses coherent with our current knowledge on Mourasuchus and on the feeding habits of crocodylomorphs. As a result, this study proposes that Mourasuchus was likely incapable of capturing and consuming large preys and specialized in eating small ones, such as mollusks, crustaceans and small fishes. The rostrum of Mourasuchus possibly evolved to cover the largest possible area, in order to be more efficient in the capture of large amounts of small preys. Whether Mourasuchus was capable to "select" the food from other material ingested with it is not yet known. In consequence, we suggest "gulp-feeding" to describe the proposed feeding habits of these animals. Mourasuchus was probably an inhabitant of quiet, shallow water bodies, where there were a broad range of habitats in which the preferred preys of this taxon dwelled. It is also proposed that the habit of Mourasuchus evolved from the durophagous habit proposed for many fossil caimanines. This hypothesis, however, has to be addressed by future studies.
\end{abstract}

Keywords: Mourasuchus, paleoecology, paleobiology, feeding habits, Caimaninae, Crocodylia.

RESUMO - O crocodiliano caimaníneo do Mioceno da América do Sul Mourasuchus é um dos crocodilomorfos mais peculiares de todos os tempos. Ele possui um incomum rostro longo, largo e dorsoventralmente achatado, mandíbulas longas e esguias e vértebras cervicais relativamente curtas. Tais características levaram estudos prévios a propor que os hábitos alimentares de Mourasuchus eram muito diferentes dos da maioria dos crocodilomorfos. Com o objetivo de melhorar significativamente o conhecimento sobre os hábitos alimentares de Mourasuchus, realizamos a revisão mais abrangente acerca desta questão para oferecer a análise mais completa sobre ela até o momento e propor novas hipóteses que sejam coerentes com o conhecimento atual sobre Mourasuchus, bem como com os hábitos alimentares dos crocodilomorfos como um todo. Como resultados, este estudo propõe que Mourasuchus era provavelmente incapaz de capturar e consumir grandes presas e se especializou em consumir presas pequenas, tais como moluscos, crustáceos e pequenos peixes. O rostro de Mourasuchus possivelmente evoluiu para abranger a maior área possível para permitir maior eficiência na captura de grandes quantidades de pequenas presas. Não se sabe ainda se Mourasuchus seria ou não capaz de "selecionar" a comida do material que ele ingeriria junto com ela. Assim, sugerimos "engolfamento" como o melhor nome para os hábitos alimentares propostos para o táxon. Mourasuchus habitava provavelmente corpos d'água quietos e rasos, que possuiriam em maior quantidade os hábitats em que viviam suas presas preferenciais. Também se propõe que o hábito de Mourasuchus evoluiu do hábito durófago proposto para muitos caimaníneos fósseis. Esta hipótese, porém, precisa ser avaliada por estudos posteriores.

Palavras-chave: Mourasuchus, paleoecologia, paleobiologia, hábito alimentar, Caimaninae, Crocodylia. 


\section{INTRODUCTION}

The fossil crocodylomorphs of the Miocene of South America comprise one of the largest, most taxonomically diverse and morphologically disparate faunas of the Crocodylomorpha clade (Langston, 1965, 2008; Gasparini, 1996; Langston \& Gasparini, 1997; Paolillo \& Linares, 2007; Salas-Gismondi et al., 2007, 2015; Riff et al., 2010; Scheyer \& Moreno-Bernal, 2010; Bona et al., 2013a; Scheyer et al., 2013; Bona \& Barrios, 2015; Moreno-Bernal et al., 2016; Scheyer \& Delfino, 2016; Souza et al., 2016; Cidade et al., 2017, 2019). This includes not only records of the extant genera Paleosuchus (Salas-Gismondi et al., 2007), Melanosuchus (Medina, 1976; Bona et al., 2017; Foth et al., 2017) and Caiman (Souza-Filho, 1987; Fortier et al., 2009; Bona \& Carabajal, 2013; Bona et al., 2013a, 2014; Fortier et al., 2014; Salas-Gismondi et al., 2015), but perhaps the most impressive examples of such diversity are the crocodylomorphs whose morphology, ecological niche and feeding habits differ substantially from those of the extant crocodylians.

These include the terrestrial predators sebecids (Langston, 1965; Paolillo \& Linares, 2007; Salas-Gismondi et al., 2007), the giant, semi-aquatic top predator Purussaurus (Barbosa-Rodrigues, 1892; Mook, 1941; Langston, 1965; Bocquentin-Villanueva et al., 1989; Aguilera et al., 2006; Aureliano et al., 2015), the durophagous caimanines Gnatusuchus, Kuttanacaiman, Globidentosuchus and Caiman wannlangstoni (Langston, 1965; Salas-Gismondi et al., 2015), and the predominantely piscivorous, longirostrine taxa represented by crocodyloids such as Charactosuchus and Brasilosuchus (Langston, 1965; Souza-Filho \& BocquentinVillanueva, 1989; Souza-Filho, 1991, 1993; Souza-Filho et al., 1993), and gryposuchinae gavialoids (Gürich, 1912; Langston, 1965; Gasparini, 1968; Sill, 1970; BocquentinVillanueva \& Buffetaut, 1981; Kraus, 1998; Brochu \& Rincón, 2004; Riff \& Aguilera, 2008; Salas-Gismondi et al., 2016).

One of the most strikingly disparate forms of the Miocene of South America is Mourasuchus, a caimanine crocodylian that exhibits a long, wide, dorsoventrally flattened rostrum (a "platyrostral-broad" rostrum according to the classification of Busbey, 1994) with a relatively small skull table (Figure 1), slender, long mandibles, (Figures 2 and 3) and cervical vertebrae relatively short anteroposteriorly (Figure 4) (see Price, 1964; Langston, 1965, 2008; Bocquentin-Villanueva, 1984; Bona et al., 2013a, 2013b; Cidade et al., 2017). The genus comprises four species: M. atopus (Langston, 1965), from the middle Miocene Honda Group of Colombia and Pebas Formation of Peru (Langston, 1965; Salas-Gismondi et al., 2015); M. amazonensis Price, 1964, from the upper Miocene Solimões Formation of Brazil (Price, 1964; Souza-Filho \& Guilherme, 2011a); M. arendsi Bocquentin-Villanueva, 1984 from the upper Miocene Urumaco Formation of Venezuela, Solimões Formation of Brazil and Ituzaingó of Argentina (Bocquentin-Villanueva, 1984; Gasparini, 1985; SouzaFilho \& Guilherme, 2011b; Scheyer \& Delfino, 2016); and M. pattersoni Cidade et al., 2017, also from the Urumaco Formation (Cidade et al., 2017).
There are also records of Mourasuchus for the lower/ middle Miocene Castilletes Formation of Colombia (MorenoBernal et al., 2016), for the middle Miocene units Fitzcarrald Arch and Pebas Formation of Peru (Salas-Gismondi et al., 2007, 2015) and Socorro Formation of Venezuela (Scheyer et al., 2013), and for the upper Miocene Solimões Formation, of Brazil (Souza-Filho \& Kischlat, 1995; Oliveira \& SouzaFilho, 2001; Scheyer \& Moreno-Bernal, 2010), Urumaco, of Venezuela (Scheyer \& Delfino, 2016) and Yecua, of Bolivia (Tineo et al., 2014).

Ever since the first descriptions, the unusual morphology of Mourasuchus has sparked a debate about how these animals captured their preys, and about what exactly would comprise such preys. Many hypotheses have been put forward: the first ones were proposed by Langston (1965), which would later be called "filter-feeding" by other authors (Riff et al., 2010; Bona et al., 2013b), while a second hypothesis, briefly discussed by Cidade et al. (2017), is that Mourasuchus would perform a feeding behaviour named as "gulp-feeding". Additionally, different studies have proposed many distinct possible prey items for Mourasuchus, including fish, crustaceans, gastropod and bivalve molluscs and even herbivory (Langston, 1965, 2008; Cidade et al., 2017).

Langston (1965) proposed three different foraging strategies for this taxon: (i) Mourasuchus could stay stopped in the water surface with an open mouth, waiting that fish and arthropods ended up entering into the mouth unwary - a strategy that had been observed in living caimanines according to the author; (ii) it could swim slowly through the water surface scooping up (presumably with a "gular sac", see below) small animals; (iii) it could forage among the mud ("mud-grubbing"), either on the margins or on the floor of the water bodies, somewhat similarly to the behavior seen in modern-day ducks, and according to Langston (1965) in extant caimanines too. In addition, Langston (1965), arguing that the teeth of Mourasuchus were too small to have a large role in food capture, stated that they would only aid in "food straining". This expression was apparently considered by later authors (Riff et al., 2010; Bona et al., 2013b) to mean the same as "filter-feeding". However, neither Langston (1965) nor later authors explained what "straining" and "filter-feeding" would specifically mean.

The first feeding strategy could certainly be performed by Mourasuchus, but we consider unlikely that such a behavior by itself would provide all the food necessary for the animal due to the relative level of randomness in food capture that arises in this process; additionally, it would not explain the peculiar cranial morphology developed by the taxon. The second behavior could also be performed, but most likely, in very quiet water bodies in order to diminish the resistance the animal would face to close the jaws under the water. The perspective of this study is that a similar behavior to the third one proposed by Langston (1965) better fits the known morphology of Mourasuchus and thus is here considered the most likely to be performed by the taxon (see an illustration in Figure 5), as will be discussed below.

Cidade et al. (2017), based on the third hypothesis of Langston (1965), suggested that the most likely behavior 
A

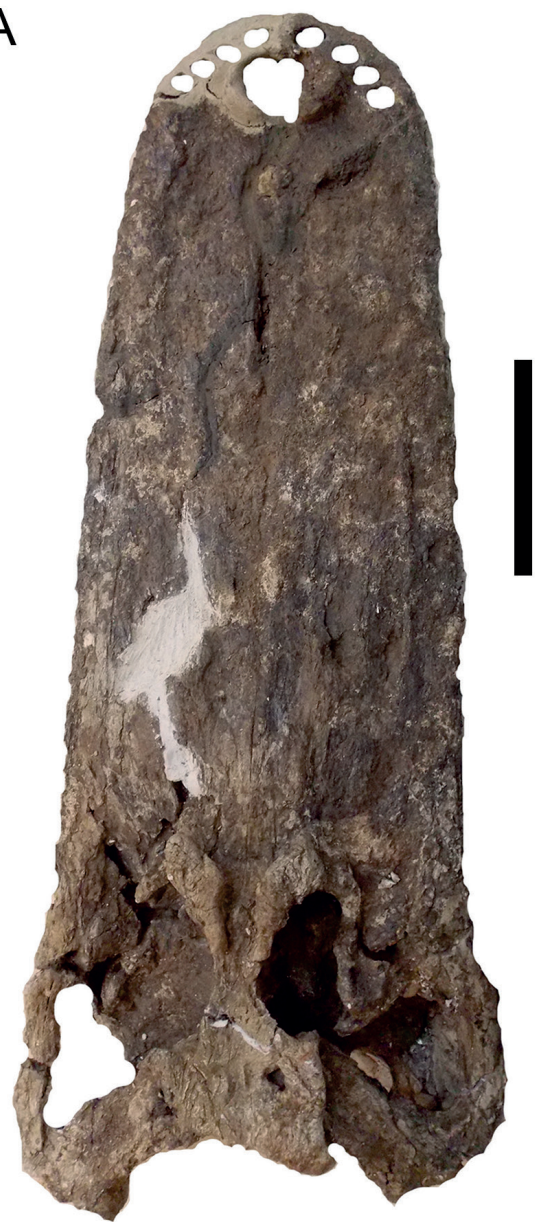

B

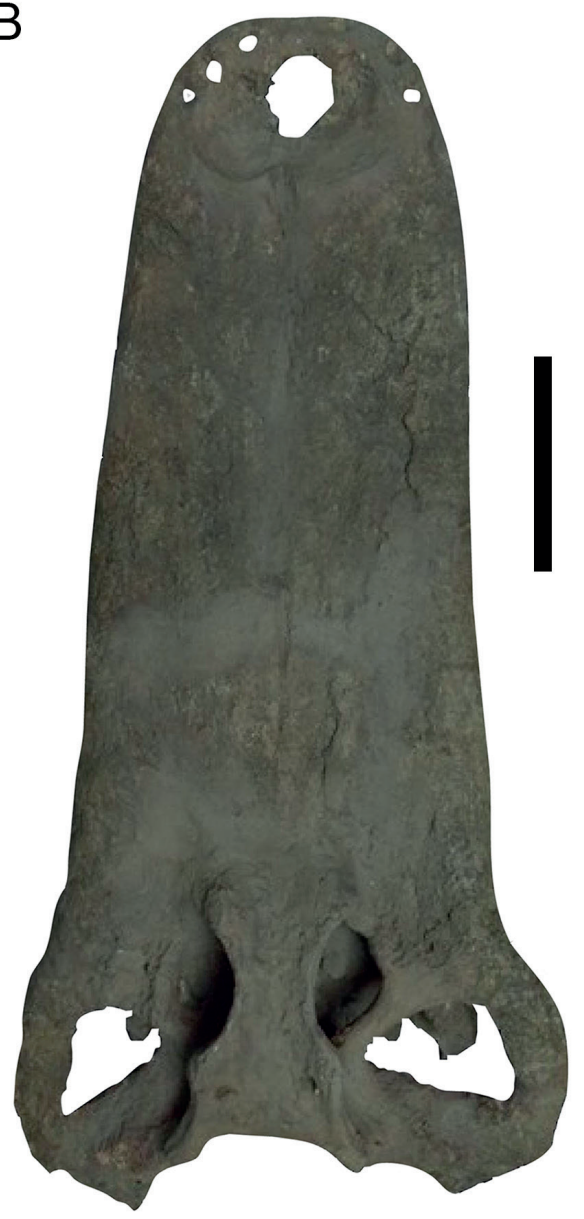

Figure 1. The platyrostral-broad skull morphology of Mourasuchus: skull of the holotypes of M. arendsi, CIAAP-1297 (A); and M. pattersoni, MCNC-PAL$110-72 \mathrm{~V}$ (B) in dorsal view. B is taken from Cidade et al. (2017, fig. 2). Scale bars $=10 \mathrm{~cm}$.

of Mourasuchus for obtaining food would be foraging through bottoms and margins of shallow water-bodies, but also emphasized briefly the role of the platyrostral-broad (see Busbey, 1994) shape of the rostrum in capturing large amounts of small preys, with the ventral portion of the rostrum serving as a "fishing net" or "gular sac". Additionally, Cidade et al. (2017) name this behavior proposed for Mourasuchus as "gulp-feeding", which would be more accurate than "filter-feeding" in describing the behavior, as the latter could imply the idea that Mourasuchus would perform techniques akin to those of baleen whales, for example. Regarding the foraging strategies and methods of ingestion of the food in Mourasuchus, this work develops on the perspectives put forward by Cidade et al. (2017) but also reviews thoroughly the hypothesis of those authors as well as those of Langston $(1965,2008)$.

Regarding the diet items of Mourasuchus, Langston (1965) suggested that these would be comprised by small fishes and arthropods. The same author posteriorly proposed (Langston, 2008) that the main diet items would be fishes of slow movement, such as Lepidosiren (Lepidosireniformes) and members of the Siluriformes group (catfish), and freshwater crabs, all of which are found in the Amazonian area of the Miocene of South America (Langston, 2008). Additionally, Langston (1965) cogitated the hypothesis that Mourasuchus could be an herbivore, since plants and algae would be easier to handle with the anatomical features of the skull and vertebrae present in the taxon.

Another interesting scenario is the notable anatomical convergence between Mourasuchus and the Cretaceous crocodyliforms from the north of Africa Stomatosuchus, Laganosuchus, Aegyptosuchus and Aegisuchus, especially in the morphology of the skull, which is also platyrostral-broad in the first two taxa, and is inferred to have the same morphology in the other two (Stromer, 1925; Sereno \& Larsson, 2009; Holliday \& Gardner, 2012). This fact meant that some similar hypotheses have been proposed regarding the feeding habits of Mourasuchus and the taxa from the African Cretaceous, most notably that the ventral portion of the rostrum serving as a "fishing net" or "gular sac" for collecting and swallowing preys (see Nopcsa, 1926; Langston, 1965; Sereno \& Larsson, 2009). 


\section{A}

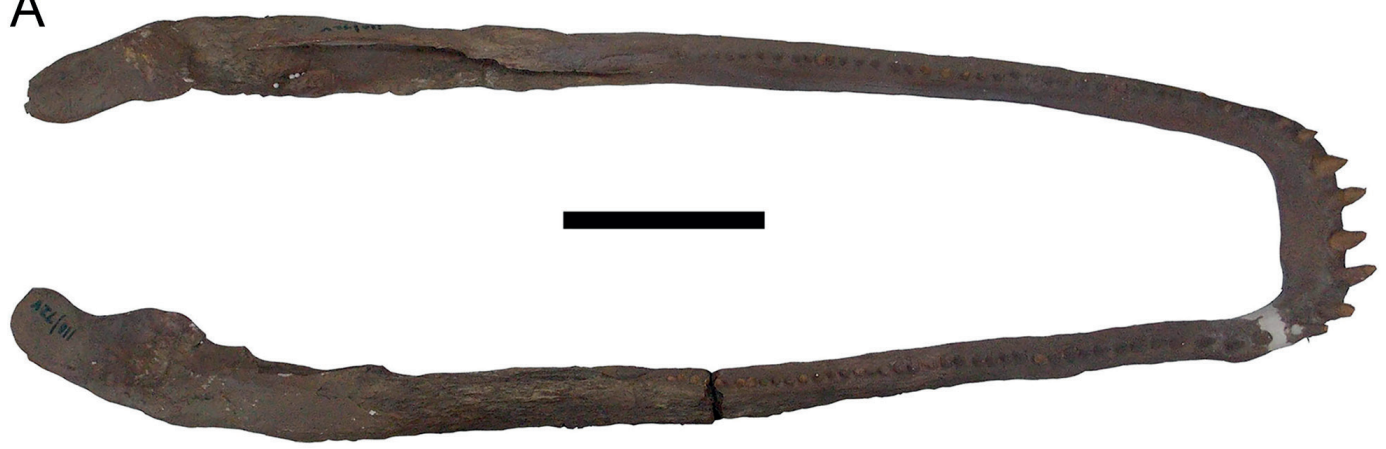

B

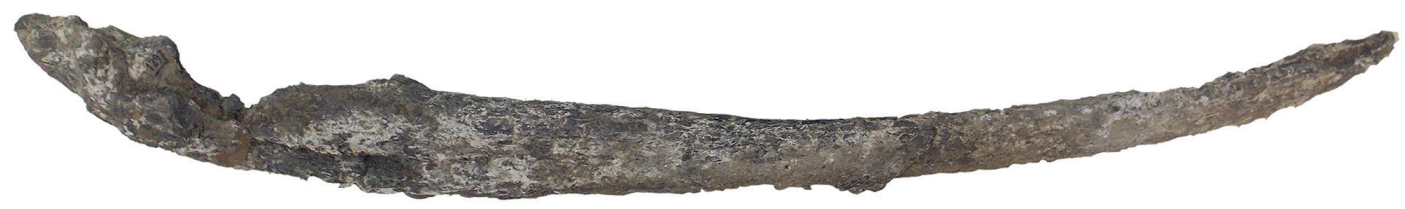

Figure 2. The long, slender mandibles of Mourasuchus: articulated right and left hemimandibles of the holotype of M. pattersoni MCNC-PAL-110-72V (A) in dorsal view and right hemimandible of the holotype of M. arendsi CIAAP-1297 (B) in dorsolateral view. A is taken from Cidade et al. (2017, fig. 4). Scale bars: $\mathrm{A}=20 \mathrm{~cm} ; \mathrm{B}=10 \mathrm{~cm}$.

\section{A}

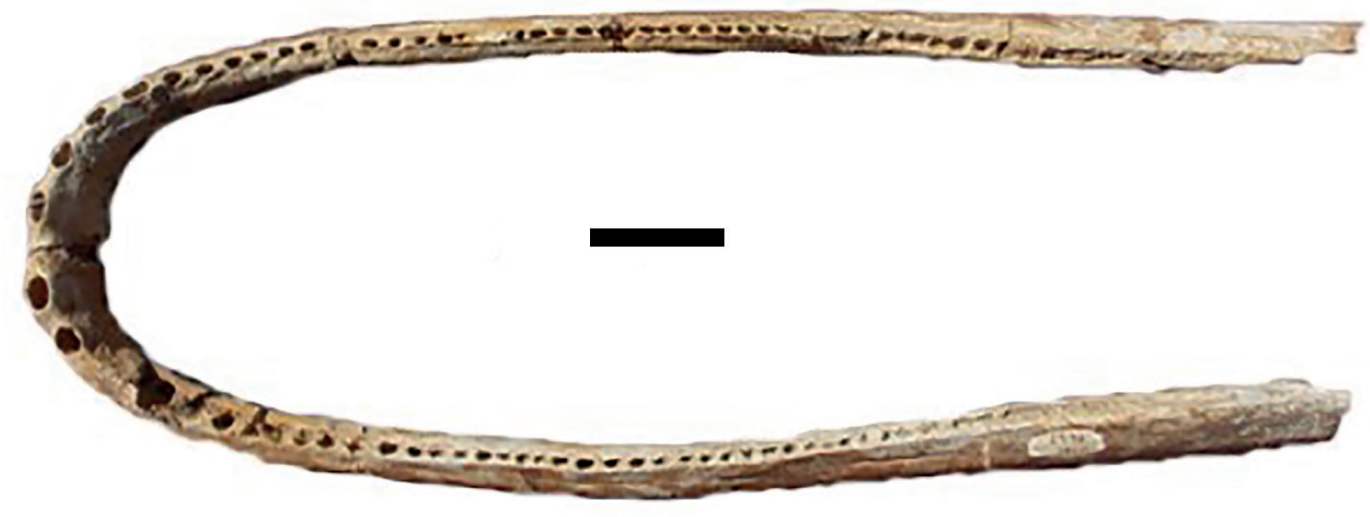

B

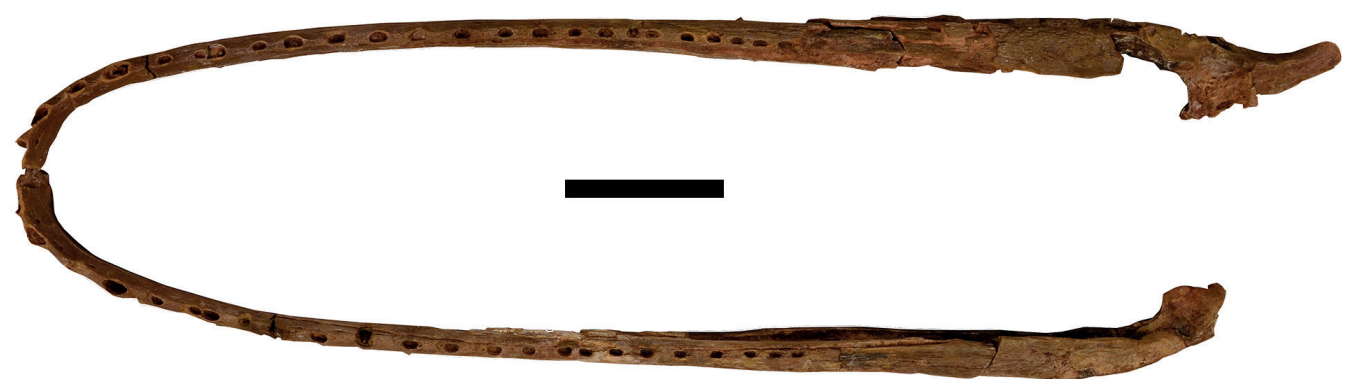

Figure 3. A right hemimandible (UFAC-2283) and a left hemimandible (UFAC-1669) of Mourasuchus (A) in dorsal view and the articulated mandibles of the holotype of Laganotushcus thaumastos (MNN IGU13; Niger; (B) in dorsal view, evidencing the similarities of the mandibular morphology of the two taxa. Scale bars: $\mathrm{A}=5 \mathrm{~cm} ; \mathrm{B}=10 \mathrm{~cm}$. 

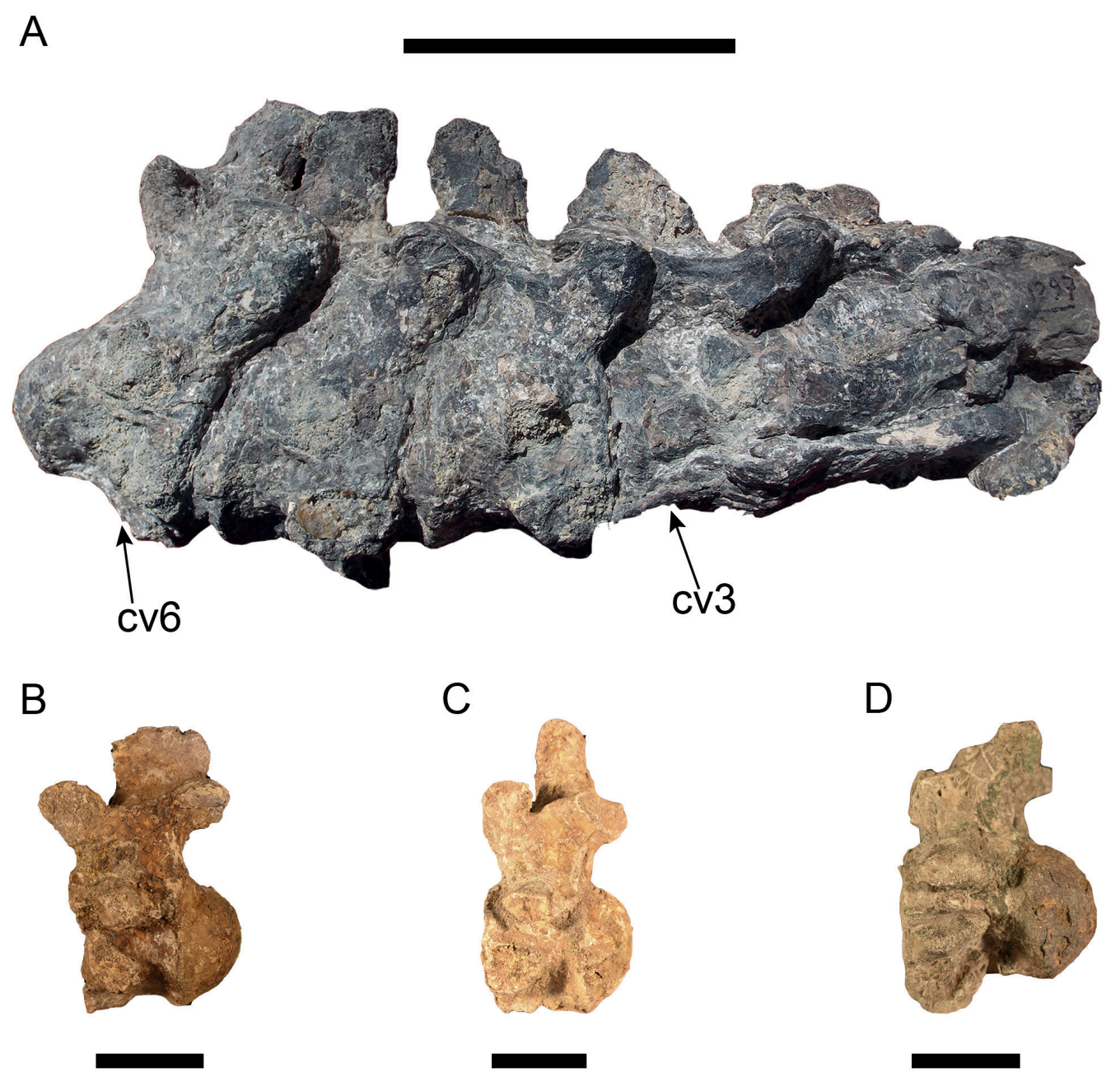

Figure 4. First six cervical vertebrae of the holotype of Mourasuchus arendsi (CIAAP-1297) in right lateral view (A) and the tentative third (B), fifth (C) and sixth (D) cervical vertebrae of the holotype of M. pattersoni (MCNC-PAL-110-72V, following the position of the vertebrae proposed by Langston, 2008). Scale bars: $A=10 \mathrm{~cm}$; $-\mathrm{D}=5 \mathrm{~cm}$.

Given these different hypotheses and scenarios, the goal of this paper is to present a comprehensive revision on the studies about the feeding habits of Mourasuchus and to discuss which hypothesis is more congruent with our current knowledge of the taxon, the paleoenvironment in which it lived and the biota with which it co-existed during the Miocene. Specifically, the three questions this study addresses are the following: how Mourasuchus captured its food?; what exactly Mourasuchus ate?; and how its unusual morphology and feeding strategy evolved, diverging from more "traditional" caimanine morphology and foraging habits.

In accordance with these objectives, comprehensive revisions were performed on the Mourasuchus anatomy related to feeding habits, the convergence between Mourasuchus and the Cretaceous crocodyliforms from northern Africa, and the antecedents on the research on Mourasuchus feeding habits. As a result of these revisions, the hypothesis defended by this work on the feeding habits of Mourasuchus is presented, along with perspectives regarding the paleoecology of this peculiar taxon.
Institutional abbreviations. CIAAP, Centro de Investigaciones Antropológicas, Arqueológicas y Paleontológicas, Universidad Nacional Experimental Francisco de Miranda, Coro, Venezuela; MCNC-PAL, Museo de Ciéncias Naturales de Caracas, Caracas, Venezuela; MNN IGU, Muséum National du Niger, Niamey, Niger; UFAC, Universidade Federal do Acre, Rio Branco, Brazil.

\section{RESULTS}

\section{Mourasuchus unusual anatomy related to feeding habits}

Both the cranial and the postcranial anatomy of Mourasuchus exhibit remarkable differences with most crocodyliforms, even if the unusual morphological disparity exhibited by the group in the Miocene of South America is considered. Many of these peculiarities were linked by previous studies to the feeding behaviour (see Langston, 1965, 2008; Bona et al., 2013b; Tineo et al., 2014; Cidade et al., 2017), which are reviewed by this study. 


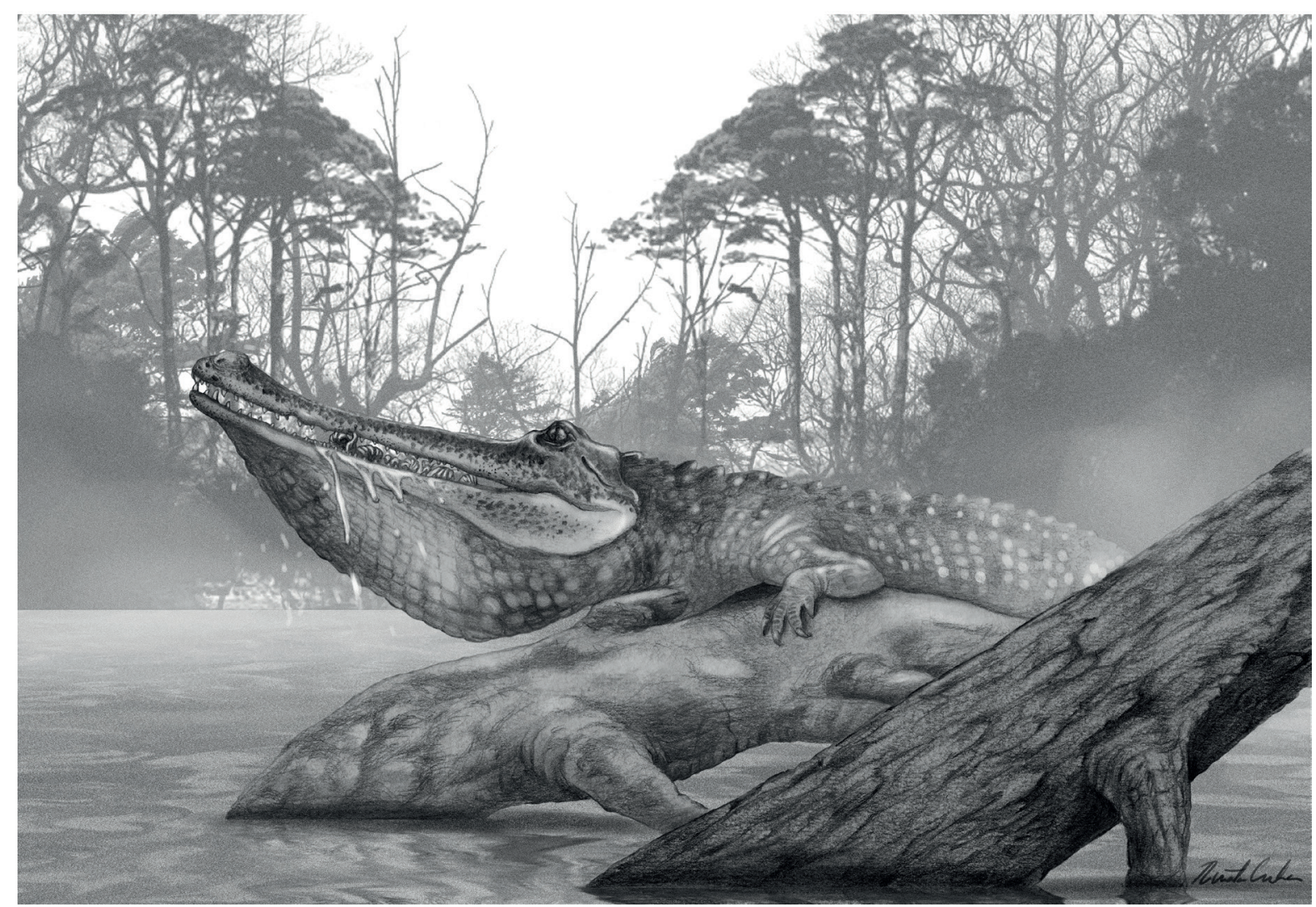

Figure 5. A paleoartistic reconstruction of how Mourasuchus could feed on invertebrate prey by paleoartist Renata Cunha.

The Mourasuchus skull has a remarkably long, wide, dorsoventrally flattened, "duck-like" platyrostral-broad rostrum (Figure 1). In accordance with the shape of the rostrum, the mandibles are long, but also lateromedially slender, with a short mandibular symphysis that does not extend beyond the level of the first mandibular alveolus (Cidade et al., 2017; Figures 2 and 3). Such skull most likely precluded Mourasuchus to capture, hold or ingest large preys in the way that many of the current crocodylians do, especially those of large size (e.g. Busbey, 1994), as it would not provide the bite force required for such activity (Langston, 1965). In addition, the shape of the rostrum would disturb the movement of the skull in water bodies with swift currents, while being met with great resistance if the animal tried to close the "duck-like" rostrum under water (Langston, 1965).

Most of the teeth of Mourasuchus are very small relative to the size of the skull. The first to the fourth alveoli are the biggest in the mandibulary tooth row and are comparable to the extant Crocodylus acutus, but from the fifth alveolous on the alveolar size of Mourasuchus tends to be smaller than those of other crocodylians (see Langston, 1965, fig. 29 ). This suggests that the teeth did not have a prominent role in the capture or handling of the prey in the mouth. As such, the morphologies of the skull and the teeth indicate that Mourasuchus was not capable of capturing or handling large or middle-sized prey, which are a prominent diet item in the adult individuals of current large crocodylians whose body length approaches that of Mourasuchus (estimated in 6.6m by Langston, 2008), such as Crocodylus porosus, $C$. niloticus, Alligator mississippiensis and Melanosuchus niger, among others.

The postcranial anatomy features of Mourasuchus that have relation to the feeding behavior corroborate these hypotheses. The cervical vertebrae of Mourasuchus arendsi and M. pattersoni are relatively anteroposteriorly shorter than those of extant crocodylians (Bocquentin-Villanueva, 1984; Langston, 2008; Figure 4), while Tineo et al. (2014) described a cervical vertebra of "Mourasuchus sp." with a short vertebral centrum from the upper Miocene of Bolivia. This suggests that the neck of Mourasuchus was "relatively weak and less motile" than that of extant crocodylians, as proposed by Langston (2008).

Langston (2008) also linked some postcranial features to biomechanical consequences related to the feeding behavior of Mourasuchus. These are the "nearly vertical" trochlear surfaces on the odontoid bone, which would indicate a shorter vertical excursion of the head than that of extant crocodylians; the small, non-hooked hypapophyses of the cervical vertebrae suggest less development of the muscle $M$. longus colli, which is involved with flexing and lateral movement of the neck; and the low cervical neural spines suggest that the epaxial antagonist muscles would be less powerful that in extant taxa (see Langston, 2008, p. 139). These features, associated with the proportionally small size of the cervical vertebrae as 
whole, led the same author to propose that the cervical area ("neck") of Mourasuchus would be relatively weaker and less motile than that of extant crocodylians.

All these suggestions still require proper biomechanical analyses to be thoroughly tested, but this work considers that the features noted by Langston (2008) indicate at least that Mourasuchus was not capable of accentuated head movements, as pointed out the same author. Thus, the vertebral anatomy agrees with the skull anatomy in indicating that this taxon was very probably not capable of holding and dismembering large prey in the way many modern crocodylians do, with behaviors such as the 'death roll' (see Blanco et al., 2015) being unlikely to be performed by Mourasuchus.

Furthermore, Tineo et al. (2014) also propose that Mourasuchus would have a reduced length of the vertebral column in comparison with extant crocodylians, which would result in a skull-length-to-body ratio hydrodynamically adverse to a typical aquatic crocodylian. This would be in agreement with the known features of vertebral anatomy of the taxon, but as no complete vertebral column of Mourasuchus has been found so far, this hypothesis needs to be seen with caution. Nevertheless, Tineo et al. (2014) also proposed that Mourasuchus would be a preferential inhabitant of "lentic, shallow aquatic habitats" (Tineo et al., 2014), such as swamps and quiet lakes. This agrees with the aforementioned proposition of Langston (1965) about the shape of the rostrum of Mourasuchus disturbing the movement of the skull in swift waters and the great resistance the animal would face to close the rostrum under water. These proposals are in agreement with the feeding habits and lifestyle proposed for Mourasuchus in this study, which is detailed below. Additionally, swamps and lakes were known to exist in the paleoenvironments Mourasuchus lived in during the Miocene (e.g. Latrubesse et al., 2010; Scheyer \& Moreno-Bernal, 2010).

\section{Convergence with North African forms of the Cretaceous}

The unusual skull morphology of Mourasuchus is convergently shared with five species of four genera from the Upper Cretaceous of north Africa: Stomatosuchus inermis Stromer, 1925, from the Baharyia Formation of Egypt; Laganosuchus thaumastos Sereno \& Larsson, 2009, from the Echkar Formation of Niger (Figure 3) and L. maghrebensis Sereno \& Larsson, 2009 from the Upper Cretaceous Kem Kem Formation of Morocco; Aegisuchus witmeri Holliday \& Gardner, 2012, also from the Kem Kem Formation; Aegyptosuchus peyeri Stromer, 1933, also from the Baharyia Formation. Stomatosuchus and Laganosuchus have been grouped together in Stomatosuchidae Stromer, 1925, whereas Aegyptosuchus and Aegisuchus have been grouped within Aegyptosuchidae Kuhn, 1936 (Holliday \& Gardner, 2012). Stomatosuchus and Laganosuchus share with Mourasuchus a long, wide, dorsoventrally flattened skull and slender mandibles with short symphyses (see Stromer, 1925; Nopcsa, 1926; Sereno \& Larsson, 2009). While skull and mandibles were described for Stomatosuchus (Stromer, 1925; Nopcsa, 1926), only mandibles were described for Laganosuchus, but a platyrostral-broad rostrum can be safely inferred for this taxon due to the long, slender mandibles that strongly resemble those of Stomatosuchus (Sereno \& Larsson, 2009; Figure 3). Aegisuchus and Aegyptosuchus do not have complete skulls or mandibles preserved, but estimations made for Aegisuchus by Holliday \& Gardner (2012) indicate that this taxon likely had a long, wide rostrum similar to that of stomatosuchids, and the phylogenetic proximity and morphological similarities between Aegyptosuchus and Aegisuchus suggest that the former possessed a similar platyrostral-broad rostrum (see Holliday \& Gardner, 2012), but further specimens of Aegyptosuchus are required for this issue to be settled.

The convergent nature of these similarities is evident for the fact that Stomatosuchidae (represented only by Laganosuchus in phylogenetic analysis, since the holotype of Stomatosuchus was destroyed during the Second World War, see Holliday \& Gardner, 2012) is phylogenetically placed as a neosuchian basal to Eusuchia (Sereno \& Larsson, 2009; Holliday \& Gardner, 2012), and Aegyptosuchidae is placed either as a sister-taxon of Crocodylia or as a clade within Crocodylia but unrelated to Alligatoroidea, the clade within Mourasuchus is situated (Holliday \& Gardner, 2012).

The morphological similarities between Mourasuchus and the Cretaceous taxa explain that similar paleoecological hypotheses have been proposed for both. Sereno \& Larsson (2009) proposed that the mandibles of Laganosuchus could not be adducted or abducted with great force. Langston (1965) had also described the mandibles of Mourasuchus as "mechanically inefficient". Consistent with this, Sereno \& Larsson (2009) suggested that Laganosuchus was a lowlying, sit-and-wait predator, while Langston (2008) described Mourasuchus as a "lie in wait" predator that inhabited quiet waters. Additionally, Langston (1965) had already suggested that Mourasuchus could have an ambush behaviour of staying immobile in the water with the mouth opened, waiting for small fish and other animals to enter it, a behaviour that has been observed in extant taxa (Langston, 1965), and that can also be proposed for Laganosuchus. Most remarkable, however, is the proposal that the musculature of the ventral part of the rostrum that could act as a "fishing net" that would allow these taxa to "collect" the prey for subsequent swallowing, presumably without any large participation of the teeth in the process. The suggestion was first made for Stomatosuchus by Nopcsa (1926), and later proposed for Mourasuchus as well (Langston, 1965; Cidade et al., 2017). Upon suggesting this mechanism for Stomatosuchus, Nopcsa (1926) proposed that the ventral portion of the rostrum of that taxon could be a contractible structure analogous to the gular sac found in pelicans, based on features such as the length and slenderness of the mandible, the presence of a "wing-like" process ventral to the posterior portion of the same element (that would serve as attachment area for the ligaments of the "gular sac"), and the fact that the "postarticular process" (interpreted here as the retroarticular process) is bent inwards relative to the mandible. In the available figures of Stomatosuchus, the inward bending of the retroarticular process is not evident, but a ventral expansion in 
the posterior portion of the mandible that may be what Nopcsa names "wing-like" process is (see Stromer, 1925, figs. 1-1a; Sereno \& Larsson, 2009, figs. 2B-2C). None of these two features, however, are present in Laganosuchus (see Sereno \& Larsson, 2009) or in Mourasuchus (see Langston, 1965; Cidade et al., 2017, 2018), but the long, slender mandibles are shared between the three taxa. However, no specific studies to determine how contractible the ventral portion of the skull was in these taxa have ever been performed. In addition, the exact role that such contraction ability could perform in the feeding process of Mourasuchus has never been thoroughly reviewed and discussed, for example through comparison with observations made in extant crocodylians about the musculature of the ventral portion of the rostrum. The latter issue is also one of the objectives of this study.

\section{Hypotheses defended in this work for the feeding habits of Mourasuchus}

The anatomy of both the skull and the cervical vertebrae makes it very unlikely that Mourasuchus was able to hold, dismember and ingest larger prey, especially if these were capable of fast movements. The only large prey Mourasuchus could eat would be those not capable of fast movements, such as the aforementioned Lepidosiren fish, but even these slow-moving preys were likely to require some strength of the skull and mandibles, as well as large and sharp teeth to be properly manipulated; all characteristics that Mourasuchus lacks. As such, it is here considered more likely that the prey of Mourasuchus would be mostly comprised of small animals.

The most consumed small animals were most likely small fish and crustaceans (e.g. fresh water crabs and shrimps), as proposed by Langston $(1965,2008)$ and Cidade et al. (2017), but also gastropod and bivalve mollusks (Cidade et al., 2017; Figure 5) which are also found in the Miocene formations of South America and which comprise the main diet items of several durophagous caimanines (see SalasGismondi et al., 2015), whose possible relation to the feeding habits of Mourasuchus will be discussed posteriorly. Insects could also make part of the diet of Mourasuchus, although presumably to a lesser extent than the eminently aquatic gastropods, bivalves and crustaceans. The consumption of these groups of invertebrates by extant crocodylians has been continuously recorded, including in living caimanines (e.g. Carvalho, 1951; Medem, 1981, 1983; Monteiro et al., 1997), especially in juvenile stages (e.g. Monteiro et al., 1997), whilst Caiman latirostris is considered to rely mainly on ampullarid gastropods also during adulthood (Diefenbach, 1979, 1987; Vanzolini \& Gomes, 1979; Ayarzagueña, 1983; Monteiro, et al., 1997; Ösi \& Barrett, 2011).

The possibility that Mourasuchus could be an herbivore is not considered here as likely, but further evidence may point to an opposite direction. Consumption of vegetal matter has been observed in living crocodylians, being it either of foliage, seeds or fruits (e.g. Brito et al., 2002; see Platt et al., 2013 for a revision); additionally, some capacity of digestion of plant carbohydrates, proteins and lipids has been detected in Alligator mississipiensis (Coulson et al., 1987; Staton,
1988; Platt et al., 2013). Herbivory has also been suggested for other fossil crocodyliforms, such as Chimaerasuchus paradoxus from Lower Cretaceous of China (Wu et al., 1995), and Simosuchus clarki, from the Upper Cretaceous of Madagascar (Buckley et al., 2000). As far as it concerns Mourasuchus, however, there are no evidences yet to support an herbivorous habit for this taxon, such as those that could be obtained through the finding and analysis of stomach or coprolite contents, for example.

The extinct caimanines Kuttanacaiman, Caiman wannlangstoni, Globidentosuchus and Gnatusuchus are considered to be durophagous taxa, feeding mainly on hardshelled invertebrates such as bivalves and gastropods (SalasGismondi et al., 2015). They are described as durophagous mainly due to the presence of posterior globular teeth and large mandibular symphyses, among other cranial features. Gnatusuchus, specifically, is considered by Salas-Gismondi et al. (2015) to have a foraging strategy of a "head burrowing" activity in which the animal predated infaunal bivalves of unconsolidated bottoms of lakes and rivers. Even though Gnatusuchus was a very specialized form for this kind of behavior, having a unique "shovel-like" structure in the lower jaws that helped to "scrape" the bottom of the water bodies (Salas-Gismondi et al., 2015), it is possible that such a strategy could be performed by all the other extinct durophagous Caimaninae taxa. The bivalve infauna in the water bodies of the Miocene of South America, where all of the aforementioned extinct taxa lived, was very rich (Wesselingh et al., 2002; Wesselingh, 2006; Salas-Gismondi et al., 2015), providing and abundant diet source for durophagous crocodylians. Given the possibility that the main prey of Mourasuchus would be the same as that of durophagous caimanines such as Gnatusuchus, we consider that the foraging behavior of Mourasuchus could be somewhat similar to that of those taxa, although exhibiting a specialization toward the swallowing of large quantities of prey without the necessity to crunch them with the teeth.

If durophagous Caimaninae such as Gnatusuchus fed burrowing the margins and floors of the water-bodies to collect their prey (especially bivalve mollusks but also gastropods, as well as crustaceans and other arthropods) and subsequently crunch them with their posterior globular teeth (a derivation from the plesiomorphic condition in crocodyliformes, which is to capture prey with the teeth and ingest without elaborate mastication), Mourasuchus could use of a similar way to capture the prey mainly in margins and bottoms of water bodies but would not crunch them with its teeth, since most of those are not only very small but also lack the globular shape seen in the typical durophagous crocodylians. Instead, Mourasuchus would swallow the prey entirely, preferably in large quantities that could be captured with the inferior part of the rostrum and then ingested all together. Such behavior would explain not only the small size of most of the teeth in Mourasuchus (Langston, 1965), as it would also explain the long, wide, dorsoventrally flattened, platyrostral-broad rostrum of this taxon, as such morphology significantly increases the area occupied by the rostrum, consequently increasing the 
efficiency and the probability of capturing large amounts of the invertebrate prey on which Mourasuchus preferably fed on (Cidade et al., 2017). It explains, furthermore, the not very efficient musculature involved in the opening of the mouth as inferred in previous works (Langston, 1965, 2008; Tineo et al., 2014). Additionally, the use of the inferior part of the rostrum to collect preys would allow the taxon to capture large amounts of preys in a more efficient way than if the capture of the prey relied more on the use of the teeth, as it is frequently observed in extant crocodylians. For these reasons, this method of prey capturing, which developed on the third proposal by Langston (1965, see above) and Cidade et al. (2017) is preferred as the main foraging technique of Mourasuchus over the other two proposed by Langston (1965, see above). The other two could also be performed by Mourasuchus, but are considered as unlikely to be the main foraging techniques: in the first (that Mourasuchus stopped in the water surface with an open mouth, waiting that fish and arthropods ended up entering into the mouth unwary), such a behavior by itself is unlikely to provide all the food necessary for the animal due to the relative level of randomness in food capture that arises in this process and it would not explain the peculiar cranial morphology developed by the taxon. The second (that Mourasuchus could swim slowly through the water surface scooping up small animals) is unlikely to be the main foraging technique due to the slenderness of the mandibles, which are thus a morphology not adapted to a foraging technique based largely on underwater dorsoventral movements of the mandible to capture prey, and thus was most likely performed occasionally and on very quiet waters.

The use of the inferior part of the rostrum to collect preys is directly linked with some capacity of contraction of the ventral portion of the rostrum. Such capacity has been observed in the extant Alligator mississippiensis, which is achieved probably by the activation of the muscles $M$. genioglossus and $M$. hyoglossus, located underneath the tongue (Busbey, 1989). As such, this contraction can also be present in Mourasuchus - pending biomechanical studies that may confirm or not its existence in this taxon - and would aid in the "gulping" of the prey in the fashion proposed above. Such contraction is reminiscent of the idea of the presence of a "gular sac", as proposed by Langston (1965). Although the expression "gular sac" could be used to denote only a contractible inferior part of the rostrum being presumably involved in the capture of the prey by Mourasuchus, we recommend that this expression should not be used to describe this structure for this taxon unless future studies eventually show the inferior part of the rostrum of Mourasuchus to have striking similarities with the gular skins found in birds like pelicans, for example. However, the role of the ventral portion of the rostrum as a contractable collecting tool for food (as a "fishing net"), regardless of the fact that it may be called a "gular sac" or not, is proposed here as a likely possibility given the inferred foraging behavior and diet items of Mourasuchus, as well as the presence of contraction of the musculature of this area seen in A. mississippiensis.
Walmsley et al. (2013) state that the crocodylian skull exhibited a "trade-off" along its evolutionary history between a long, slender rostrum that provided speed, and a shorter, yet more robust rostrum that provide strength in biting and consequently in the capture of prey. In this context, as argued by Cidade et al. (2017), Mourasuchus presents an interesting case in which the rostrum does not provide either speed or strength to the biting of the living individual; instead, an increase in area to optimize the capture of preferentially a large amount of small prey seems to be the great advantage this rostral morphology provided to the individuals of Mourasuchus.

This foraging strategy aforementioned described for Mourasuchus has been named as "gulp-feeding" (Cidade et al., 2017) to emphasize the process of collecting and swallowing the food that were performed by the taxon, instead of the term "filter-feeding", which denotes the performing of a selection process on the food for which there is no evidence yet in Mourasuchus. However, the small invertebrate animals on which Mourasuchus would mainly feed would not be found separate from the microenvironment in which they live in, with these being either biotic - plants, algae - or abiotic - water, mud, sand, etc (Cidade et al., 2017). As such, Mourasuchus could rarely obtain its food in the aforementioned described way without also carrying into its mouth a certain amount of any of these materials, and thus it would be useful for the animal to develop a selection procedure to separate the edible matter from the non-edible matter (mud, water, etc.) that came with the former (Cidade et al., 2017). Such selection procedure may be what Langston (1965) described as "straining technique", which later authors (e.g. Riff et al., 2010; Bona et al., 2013b) would refer to as a filtering or "filter-feeding" technique, even though none of this works give a detailed description of how these techniques would function.

Nevertheless, the possibility that Mourasuchus performed a procedure akin to a "selection" of the material put in the mouth before swallowing is considered here as plausible. Langston (1965) suggested that the tongue could be used to perform this procedure, as it could be elevated pressuring the water against the upper palate until the water could be expelled between the teeth, leaving the edible material concentrated for swallowing. Another possibility is that this movement proposed for the tongue by Langston (1965) could be performed by the muscles positioned between both mandibular rami in the inferior part of the rostrum. Living crocodylians have been observed to use such behavior exactly to expel water from the mouth between the teeth (Daniel C. Fortier, pers. com.). Nevertheless, our current knowledge on Mourasuchus does not allow inferring whether this taxon was really capable of performing such selection or not (Cidade et al., 2017), and as such we favorable "gulp-feeding" as a better name to the proposed feeding habits of Mourasuchus.

The proposed similarities allow the suggestion that the feeding behavior of Mourasuchus would have evolved from the durophagous feeding habit of caimanines such as Gnatusuchus. However, Caimaninae phylogenetic analyses 
that include the durophagous taxa and Mourasuchus (SalasGismondi et al., 2015; Cidade et al., 2017) do not recover the latter as closely related to any of the former. These topologies indicate that the feeding habits of Mourasuchus have evolved independently from that of the durophagous Caimaninae. Future analyses, however, may reveal different scenarios.

Nevertheless, a durophagous habit is already known to have arisen more than once in the Alligatoroidea clade, with basal alligatoroids such as Brachychampsa and alligatorines such as Allognathosuchus also being described as having been durophagous (see Carpenter \& Lindsay, 1980; Brochu, 2004; Salas-Gismondi et al., 2015). As such, a possible scenario for the independent evolution of the "gulp-feeding" habit of Mourasuchus within Caimaninae is that it may have evolved from the habit of swallowing prey without masticating (which is plesiomorphic within crocodyliformes), which gradually evolved with the enlargement of the rostrum to allow a large number of small prey to be captured simultaneously, whereas the durophagy of the other Caimaninae could be seen as a specialization of the use of the posterior globular teeth against hard-bodied prey, having evolved probably from an ancestor that exhibit a feeding behavior similar to the extant Caiman latirostris (see Monteiro et al., 1997; Ösi \& Barrett, 2011).

\section{DISCUSSION}

\section{Perspectives}

The comprehensive revision and the detailed hypotheses presented in this study comprise the most complete assessment on the feeding habits of Mourasuchus published to date. However, both the hypotheses presented in this study and those presented by previous ones still need to be properly tested and assessed empirically.

The proposed reduced capacity of movement of the neck by Mourasuchus inferred by Langston (2008) still needs to be properly assessed in a biomechanical analysis. Similarly, even if the slender mandibles of Mourasuchus have low mechanical capacities in all likelihood, a quantitative measurement of such mechanical capacities is also still in need to be done by proper biomechanical studies. Additionally, biomechanical studies in addition with muscular reconstructions may examine how elastic the musculature of the inferior part of the rostrum of Mourasuchus could be so to test whether (or to which level) it could act as analogous to a "gular sac". The same studies are necessary to investigate whether (and if yes, how) Mourasuchus could select the edible from the edible-matter that it introduced into its mouth in order not to ingest a significant amount of water, mud, sand, plants or other materials.

Additionally, more fossil findings and further phylogenetic analyses are required to clarify where Mourasuchus exactly fits in the phylogeny of Caimaninae. This is fundamental to understand how the unusual feeding habits of the taxon evolved. The hypothesis that the habit of Mourasuchus evolved from a durophagous one exhibited by several caimanine taxa has been put forward by this study, but further phylogenetic studies must find a close relationship between Mourasuchus and those taxa (which has not been recovered in the analyses performed to date; see Salas-Gismondi et al.,
2015; Cidade et al., 2017) in order for this hypothesis to be more plausible. Additionally, new fossils may bring some direct evidence of the dietary items of Mourasuchus, such as stomach contents or remains of food in coprolites, any of which have not been found to date.

\section{The historical paleoecology of South American crocodylomorphs}

The evolution of the peculiar feeding of Mourasuchus is another consequence of the environmental conditions that allowed the establishment of an especially rich, morphologically diverse community of crocodylomorphs in the Miocene of South America. In this context, it is interesting to notice that from the four lineages that comprised such Miocene diversity (Sebecidae, Caimaninae, Gavialoidea and Crocodyloidea), two of them were already inhabiting South America by the Paleocene (Sebecidae and Caimaninae; see Bona, 2007; Riff et al., 2010; Brochu, 2011; Pol \& Powell, 2011; Kellner et al., 2014; Cidade et al., 2019), while the first record of Gavialoidea for the continent is from the upper Oligocene/lower Miocene (Moraes-Santos et al., 2011) and the first records of Crocodyloidea (the putative tomistomine genera Charactosuchus and Brasilosuchus) are from the Miocene (see Riff et al., 2010), whereas the genus Crocodylus that currently inhabits the continent has its record beginning only in the Pliocene (Scheyer et al., 2013).

Of all these four lineages, Caimaninae is the one that exhibits the largest and most conspicuous morphological disparity in the Miocene, possessing morphotypes ranging from generalist predators (Melanosuchus, Paleosuchus), predominately durophagous (Gnatusuhcus, Kuttanacaiman, Globidentosuchus, Caiman brevirostris), the giant generalist predator Purussaurus and the gulp-feeding Mourasuchus (Cidade et al., 2019). These two taxa were also especially large crocodylians, with Mourasuchus reaching up to $6.6 \mathrm{~m}$ (Langston, 2008) and Purussaurus up to $12.5 \mathrm{~m}$. (Aureliano et al., 2015). Some gavialoids and sebecids also reached large sizes, with Gryposuchus croizati estimated to have reached between 9 and $10 \mathrm{~m}$ (Riff \& Aguilera, 2008) and Barinasuchus arveloi between 6.3 and over $10 \mathrm{~m}$ (Molnar \& Vasconcellos, 2016). However, Gavialoidea, putative tomistomines and Crocodylus exhibited basically the same bauplan along their evolutionary history in the South American Cenozoic, including the Miocene. Sebecidae is an exception, in which the species Lorosuchus nodosus exhibits a platyrostral skull that denotes a semi-aquatic habit, different from the terrestrial habit possessed by the other members of the taxa (Pol \& Powell, 2011). Nevertheless, this still contrasts deeply with the large morphological disparity exhibited among the Caimaninae taxa.

Compared to caimanines and sebecids, Gavialoids and crocodyloids probably did not develop a similar morphological disparity in the Miocene of South America due to having arrived later in the continent. Additionally, not only the gavialoids but also the crocodyloids that inhabited the South American Miocene were longirostrine, and it is possible that such skull shape would be less "plastic" than a brevirostrine one, thus precluding these taxa of exhibiting a 
larger morphological disparity. These hypotheses, however, require further, detailed research to be properly addressed.

The differences in morphological disparity between caimanines and sebecids may be related to the semi-aquatic habits of the former and the terrestrial habits of the latter. The northern part of the South America, equivalent to the area of the current Amazon rainforest and which houses the largest crocodylomorph diversity during the Cenozoic of the continent, including the Miocene, underwent gradual geomorphological changes during the Paleogene and the Neogene that gradually increased the size of the water-bodies from a series of rivers to systems of mega-lakes (see Hoorn et al., 2010).

As such, semi-aquatic crocodylomorphs had not only an ever-growing habitable space but also had ever-growing different kinds of habitats in the aquatic systems of the Cenozoic of South America which, together with the generally hot climate and high biodiversity (which generated a vast array of prey items), were the factors that allowed the Caimaninae clade to evolve the distinctly different morphotypes it exhibited in the Miocene, including the "gulp-feeding" habit of Mourasuchus. In this context, it is interesting to notice that the reduction in the size of the water systems of the Amazon area during and after the late Miocene are coincident with the extinction of all the large and specialized crocodylomorphs, such as Mourasuchus, Purussaurus, durophagous caimanines, gavialoids and the longirostrine crocodyloids Charactosuchus and Brasilosuchus (see Riff et al., 2010; Scheyer et al., 2013; Cidade et al., 2019), which reinforces the importance of large water systems for the survival and evolution of large, specialized semi-aquatic crocodylomorphs. Additionally, it is also possible that the sebecid terrestrial-oriented morphology was also less "plastic" that that of the semiaquatic, brevirostrine caimanines, but this issue must also be addressed by future, detailed studies.

\section{CONCLUSIONS}

As a result of the comprehensive revision and reassessment of the literature and morphological characters relevant to the understanding of the feeding habits of Mourasuchus, this study concludes that the taxon was likely unable of capturing and consuming large prey, especially those capable of fast movements such as mammals. As such, Mourasuchus was likely specialized in eating small preys, such as crustaceans, bivalves, gastropods, and small fish. Large preys would only be consumed if they were slow-moving, like the Lepidosiren fish, and likely only occasionally. There are no evidences that Mourasuchus was herbivorous.

We propose that the long, wide, dorsoventrally flattened rostrum of Mourasuchus evolved as to make the rostrum cover the largest possible area to allow a maximum efficiency in the capture of large amounts of small prey. The use of the inferior part of the rostrum would be more efficient in the capture of large amounts of prey than relying on teeth to capture and handle the small animals that likely comprised the diet items of Mourasuchus. In spite of the inferred prominent role that the inferior part of the rostrum played in the foraging of Mourasuchus, it is recommended that the term "gular sac" should not be used to describe this structure for this taxon until eventual further studies determine whether it functioned in an analogous manner to the gular skin present in extant birds, for example.

As the small animals proposed to have comprised the main diet items of Mourasuchus would nearly always be found immersed into the micro-habitat they lived in (water, mud, sand or plants, among others), it is probable that Mourasuchus also captured quantities of these materials together with the prey. As such, some sort of "selection" of the edible from the non-edible matter somewhat akin to the "filtering" mentioned by previous authors (Langston, 1965; Riff et al., 2010; Bona et al., 2013b) would be advantageous to Mourasuchus, but with our current knowledge there are no evidences that such a selection could be performed by this taxon. As such, we follow Cidade et al. (2017) in naming the presumable feeding habits of Mourasuchus as "gulp-feeding", and not "straining" or "filtering" feeding as in those previous studies. Mourasuchus was most probably a inhabitant of quiet, shallow water bodies, not only due to the presumable mechanical inefficiency of its jaws, skull and cervical vertebrae, but also because water bodies such as those possessed the largest quantity of habitats in which the preferred prey of the taxon-mollusks, crustaceans and small fish - dwelled.

This study proposed the hypothesis that the "gulp-feeding" habit of Mourasuchus evolved from the durophagous habit proposed for many fossils caimanines, particularly the highly adapted Gnatusuchus. This hypothesis, however, needs to be properly addressed by future studies, and no phylogenetic analysis performed to date showed a close relationship between Mourasuchus and any durophagous taxa, which means a hindrance to the acceptance of this hypothesis. Additionally, many hypothesis of this and previous studies about the inferred limited movements and lack of strength of the bones, osseous structures and muscles of the mandibles, skull and the cervical vertebrae still need to be properly assessed by biomechanical and muscular reconstruction studies so a thorough and more empirically-based understanding of the feeding habits of Mourasuchus can be reached.

\section{ACKNOWLEDGEMENTS}

The first author thanks the following people for access to the specimens and collections under their care: H. Moreno (MCNC), G. Oneda (CIAAP), C. Sagebiel (Texas Memorial Museum, Austin, United States), J. Cundiff (Museum of Comparative Zoology, Cambridge, United States), J.P. de Souza-Filho and A. Maciente (UFAC). P. Godoy (University of Birmingham, Birmingham, United Kingdom) and F. Montefeltro (Universidade Estadual Paulista, Ilha Solteira, Brazil) are thanked for pictures of Laganosuchus. We thank the editor J. Cisneros and an anonymous reviewer for suggestions and corrections that greatly improved the manuscript. The fist author deeply thanks D. Fortier (Universidade Federal do Piauí, Floriano, Brazil) for discussions that significantly improved earlier drafts of this paper. Paleoartist R. Cunha is thanked for the drawing of Figure 5. This study was funded by Fundação de Amparo à Pesquisa do Estado de São Paulo 
(FAPESP) Master's Degree scolarship 2013/04516-1, by the Conselho de Desenvolvimento Científico e Tecnológico (CNPq) Doctorade scholarship 140808/2016-7 and by the Coordenacão de Aperfeiçoamento de Pessoal de Nível Superior (CAPES) grant [Finance Code 001] to GMC, FAPESP research grant 2011/14080-0 and CNPq research grant 309434/2015-7 to A.S.H and Fundação de Amparo à Pesquisa do Estado de Minas Gerais (FAPEMIG) grant APQ-00581-09 to D.R.

\section{REFERENCES}

Aguilera, O.A.; Riff, D. \& Bocquentin-Villanueva, J. 2006. A new giant Purussaurus (Crocodyliformes, Alligatoridae) from the upper Miocene Urumaco Formation, Venezuela. Journal of Systematic Palaeontology, 4:221-232. doi:10.1017/ S147720190600188X

Aureliano, T.; Ghilardi, A.M.; Guilherme, E.; Souza-Filho, J.P.; Cavalcanti, M. \& Riff, D. 2015. Morphometry, bite-force, and paleobiology of the Late Miocene Caiman Purussaurus brasiliensis. PLoS ONE, 10:e0117944. doi:10.1371/journal. pone. 0124188

Ayarzaguena, J. 1983. Ecologia del caiman de anteojos o baba (Caiman crocodilus L.) en los llanos de Apure (Venezuela). Donana Acta Vertebrata, 10:1-34.

Barbosa-Rodrigues, B. 1892. Les Reptiles fossiles de la vallée de 1'Amazone. Vellosia, 2:41-46.

Blanco, R.E.; Jones, W.W. \& Villamil, J. 2015. The 'death roll' of giant fossil crocodyliforms (Crocodylomorpha: Neosuchia): allometric and skull strength analysis. Historical Biology, 27:514-524. doi:10.1080/08912963.2014.893300

Bocquentin-Villanueva, J. 1984. Un nuevo Nettosuchidae (Crocodylia, Eusuchia) proveniente de la Formación Urumaco (Mioceno Superior), Venezuela. Ameghiniana, 21:3-8.

Bocquentin-Villanueva, J.C. \& Buffetaut, E. 1981. Hesperogavialis cruxenti n. gen., n. sp., nouveau gavialide (Crocodylia, Eusuchia) $\mathrm{du}$ Miocène Supériur (Huayquerien) d'Urumaco (Venezuela). Geobios, 14:415-419.doi:10.1016/S0016-6995(81)80184-2

Bocquentin-Villanueva, J.C.; Souza-Filho, J.P.; Buffetaut, E. \& Negri, F.R. 1989. Nova interpretação do gênero Purussaurus (Crocodylia, Alligatoridae). In: CONGRESSO BRASILEIRO DE PALEONTOLOGIA, 11, 1989. Anais, Curitiba, SBP, p. 427-438.

Bona, P. 2007. Una nueva especie de Eocaiman Simpson (Crocodylia, Alligatoridae) del Paleoceno Inferior de Patagonia. Ameghiniana, 44:435-445.

Bona, P. \& Barrios, F. 2015. The Alligatoroidea of Argentina: an update of its fossil record. Buenos Aires, Asociación Paleontológica Argentina, p. 143-158 (Publicación Electrónica 15). doi:10.5710/PEAPA.15.06.2015.103

Bona, P. \& Carabajal, A.P. 2013.Caiman gasparinae sp. nov., a huge alligatorid (Caimaninae) from the late Miocene of Paraná, Argentina. Alcheringa, 37:462-473. doi:10.1080/03115518.20 13.785335

Bona, P.; Degrange, F.J. \& Fernández, M.S. 2013a. Skull anatomy of the bizarre crocodylian Mourasuchus nativus (Alligatoridae, Caimaninae). The Anatomical Record, 296:227239. doi:10.1002/ar.22625

Bona, P.; Fernandez-Blanco, M.V.; Scheyer, T.M. \& Foth, C. 2017. Shedding light on the taxonomic diversity of the South American Miocene caimans: the status of Melanosuchus fisheri (Crocodylia, Alligatoroidea). Ameghiniana, 54:681-687. doi:10.5710/AMGH.08.06.2017.3103
Bona, P.; Riff, D. \& Gasparini, Z. 2013b. Late Miocene crocodylians from Northeast Argentina: new approaches about the austral components of the Neogene South American crocodylian fauna. Earth and Environmental Science Transactions of the Royal Society of Edinburgh, 103:1-20. doi:10.1017/ S175569101300042X

Bona, P.; Starck, D.; Galli, C.; Gasparini, Z. \& Reguero, M. 2014. Caiman cf. latirostris (Alligatoridae, Caimaninae) in the late Miocene Palo Pintado Formation, Salta Province, Argentina: paleogeographic and paleoenvironmental considerations. Ameghiniana, 51:26-36. doi:10.5710/AMGH.11.12.2013.1507

Brito, S.P.; Andrade, D.V. \& Abe, A.S. 2002. Do Caimans eat fruit? Herpetological Natural History, 9:95-96.

Brochu, C.A. 2004. Alligatorine phylogeny and the status of Allognathosuchus Mook, 1921. Journal of Vertebrate Paleontology, 24:856-872. doi:10.1671/02724634(2004)024[0857:APATSO]2.0.CO;2

Brochu, C.A. 2011. Phylogenetic relationships ofNecrosuchus ionensis Simpson, 1937 and the early history of caimanines. Zoological Journal of the Linnean Society, 163:S228-S256. doi:10.1111/j.1096-3642.2011.00716.x

Brochu, C.A. \& Rincón, A.D. 2004. A gavialoid crocodylian from the Lower Miocene of Venezuela. London, The Palaeontological Association, p. 61-78 (Special Papers in Palaeontology 71).

Buckley, G.A.; Brochu, C.A.; Krause, D.W. \& Pol, D. 2000. A pugnosed crocodyliform from the Late Cretaceous of Madagascar. Nature, 405:941-944.doi:10.1038/35016061

Busbey, A.B. 1989. Form and function of the feeding apparatus of Alligator mississippiensis. Journal of Morphology, 202:99-127. doi:10.1002/jmor.1052020108

Busbey, A.B. 1994. The structural consequences of skull flattening in crocodylians. In: J.J. Thomason (ed.) Functional morphology in vertebrate paleontology, Cambridge University Press, p. 173-192.

Carpenter, K. \& Lindsey, D. 1980. The dentary of Brachycharnpsa montana Gilmore (Alligatorinae, Crocodylidae), a Late Cretaceous turtle-eating alligator. Journal of Paleontology, 54:1213-1217.

Carvalho, A.L. 1951. Os jacarés do Brasil. Arquivos do Museu Nacional, 43:127-152.

Cidade, G.M.; Fortier, D. \& Hsiou, A.S. 2019. The crocodylomorph fauna of the Cenozoic of South America and its evolutionary history: a review. Journal of South American Earth Sciences, 90:392-411. doi:10.1016/j.jsames.2018.12.026

Cidade, G.M.; Solórzano, A.; Rincón, A.D.; Riff, D. \& Hsiou, A.S. 2017. A new Mourasuchus (Alligatoroidea, Caimaninae) from the late Miocene of Venezuela, the phylogeny of Caimaninae and considerations on the feeding habits of Mourasuchus. PeerJ, 5:e3056. doi:10.7717/peerj.3056

Cidade, G.M.; Solórzano, A.; Rincón, A.D.; Riff, D. \& Hsiou, A.S. 2018. Redescription of the holotype of the Miocene crocodylian Mourasuchus arendsi (Alligatoroidea, Caimaninae) and perspectives on the taxonomy of the species. Historical Biology. doi:10.1080/08912963.2018.1528246.

Coulson, R.A.; Coulson, T.D.; Herbert, J.D. \& Staton, M.A. 1987. Protein nutrition in the alligator. Comparative Biochemistry and Physiology Part A: Physiology, 87:449-459. doi:10.1016/03009629(87)90150-2

Diefenbach, C.O.C. 1979. Ampullarid gastropod - staple food of Caiman latirostris? Copeia, 1979:162-163.

Diefenbach, C.O.C. 1987. Thermal and feeding relations of Caiman latirostris (Crocodylia: Reptilia). Comparative Biochemistry and 
Physiology Part A: Physiology, 89:149-155. doi:10.1016/03009629(88)91072-9

Fortier, D.; Brochu, C.A. \& Souza-Filho, J.P.2009. The oldest record of Caiman yacare. Journal of Vertebrate Paleontology, 29:97A.

Fortier, D.C.; Souza-Filho, J.P.; Guilherme, E.; Maciente, A. \&Schultz, C.L. 2014. A new specimen of Caiman brevirostris (Crocodylia, Alligatoridae) from the Late Miocene of Brazil. Journal of Vertebrate Paleontology, 34:820-834. doi:10.1080/ 02724634.2014 .838173

Foth, C.; Fernandez-Blanco, M.V.; Bona, P. \& Scheyer, T.M. 2018. Cranial shape variation in jacarean caimanines (Crocodylia, Alligatoroidea) and its implications in the taxonomic status of extinct species: the case of Melanosuchus fisheri. Journal of Morphology, 279:259-273. doi:10.1002/jmor.20769

Gasparini, Z. 1968. Nuevos restos de Rhamphostomopsis neogeaeus (Burm.) Rusconi, 1933, (Reptilia, Crocodilia) del “Mesopotamiense' (Plioceno medio-superior) de Argentina. Ameghiniana, 5:299-311.

Gasparini, Z. 1985. Un nuevo cocodrilo (Eusuchia) Cenozoico de América del Sur. Rio de Janeiro, MME-DNPM, p. 51-53 (Coletânea de Trabalhos Paleontológicos 27).

Gasparini, Z.1996. Biogeographic evolution of the South American crocodylians. Munchner Geowissenschaftliche Abhandlungen, 30:159-184.

Gürich, G. 1912. Gryposuchus jessei ein neues schmalschnauziges Krokodil aus den jüngeren Ablagerungen des obreren AmazonasGeibetes. Mitteilungen aus dem Mineralogisch-Geologischen Institut in Hamburg, 29:59-71.

Holliday, C.M. \& Gardner, N.M. 2012. A new Eusuchian Crocodyliform with novel cranial integument and its significance for the origin and evolution of Crocodylia. PLOS ONE, 7:e30471. doi:10.1371/journal.pone.0030471

Hoorn, C. et al. 2010. Amazonia through time: Andean uplift, climate change, landscape evolution, and biodiversity. Science, 330:927-931. doi:10.1126/science.1194585

Kellner, A.W.A.; Pinheiro, A.E.P. \& Campos, D.A. 2014. A new sebecid from the Paleogene of Brazil and the Crocodyliform radiation after the K-Pg boundary. PLOS ONE, 9:e81386. doi:10.1371/journal.pone.0081386

Kraus, R. 1998. The cranium of Piscogavialis jugaliperforatus n. gen., n. sp. (Gavialidae, Crocodylia) from the Miocene of Peru. Paläontologische Zeitschrift, 72:389-406. doi:10.1007/ bf02988368

Langston, W. 1965. Fossil crocodylians from Colombia and the Cenozoic history of the Crocodilia in South America. Davies, University of California, 168 p. (Publications in Geological Sciences 66)

Langston,W. 2008. Notes on a partial skeleton of Mourasuchus (Crocodylia, Nettosuchidae) from the Upper Miocene of Venezuela. Arquivos do Museu Nacional, 66:125-143

Langston,W. \& Gasparini, Z. 1997. Crocodylians, Gryposuchus, and the South American gavials. In: R.F. Kay; R.H. Madden; R.L. Ciffelli \& J.J. Flynn (eds.) Vertebrate paleontology in the neotropics: the Miocene fauna of La Venta, Colombia, Smithsonian Institution, p. 113-154.

Latrubesse, E.M.; Cozzuol, M.; Silva-Caminha, S.A.F.; Rigsby, C.A.; Absy, M.L. \& Jaramillo, C. 2010. The Late Miocene paleogeography of the Amazon Basin and the Evolution of the Amazon River system. Earth-Science Reviews, 99:99-124. doi:10.1016/j.earscirev.2010.02.005

Medem, F. 1981. Los Crocodylia de Sur America, volume 1: los Crocodylia de Colombia. Bogota, Universidad Nacional de Colombia, $354 \mathrm{p}$.
Medem, F. 1983. Los Crocodylia de Sur America, volume 2. Bogota, Universidad Nacional de Colombia, 270 p.

Medina, C.J. 1976. Crocodylians from the Late Tertiary of Northwestern Venezuela: Melanosuchus fisheri sp. nov. Breviora, 438:1-14.

Molnar, R.E. \& Vasconcellos, F. 2016. Cenozoic dinosaurs in South America - revisited. Memoirs of Museum Victoria, 74:363-377.

Monteiro, L.R.; Cavalcanti, M.J. \& Sommer, H.J.S. 1997. Comparative ontogenetic shape changes in the skull of Caiman species (Crocodylia, Alligatoridae). Journal of Morphology, 231:53-62. doi:10.1002/(SICI) 1097-4687(199701)231:1<53::AIDJMOR5>3.0.CO;2-P

Mook, C.C. 1941. A new fossil from Colombia. Proceedings of the United States National Museum, 91:55-61.

Moraes-Santos, H.; Villanueva, J.B. \& Toledo, P.M. 2011. New remains of a gavialoid crocodylian from the late Oligoceneearly Miocene of the Pirabas Formation, Brazil. Zoological Journal of the Linnean Society, 163:132-39. doi:10.1111/j.10963642.2011.00710.x

Moreno-Bernal, J.W.; Head, J. \& Jaramillo, C.A. 2016. Fossil crocodylians from the High Guajira Peninsula of Colombia: Neogene faunal change in northernmost South America. Journal of Vertebrate Paleontology, 36:e1110586. doi:10.1080/027246 34.2016.1110586

Nopcsa, F. 1926. Neue Beobachtungen an Stomatosuchus. Centralblatt für Mineralogie, Geologie und Paläontologie B, 1926:212-215.

Oliveira, M.R.S. \& Souza-Filho, J.P. 2001. Distribuição geográfica da família Nettosuchidae (Crocodyliformes) na Amazônia sulocidental (Estado do Acre). In: CONGRESSO BRASILEIRO DE PALEONTOLOGIA, 17, 2001. Boletim de Resumos, Rio Branco, p. 150.

Ösi, A. \& Barrett, P.M. 2011. Dental wear and oral food processing in Caiman latirostris: analogue for fossil crocodylians with crushing teeth. Neues Jahrbuch für Geologie und Paläontologie, Abhandlungen, 261:201-207. doi:10.1127/0077-7749/2011/0161

Paolillo, A. \& Linares, O.J. 2007. Nuevos cocodrilos Sebecosuchia del Cenozoico sudamericano (Mesosuchia: Crocodylia). Paleobiologia Neotropical, 3:1-25.

Platt, S.G.; Elsey, R.M.; Liu, H.; Rainwater, T.R.; Nifong, J.C.; Rosenblatt, A.E.; Heithaus, M.R. \& Mazzotti, F.J. 2013. Frugivory and seed dispersal by crocodylians: an overlooked form of saurochrory? Journal of Zoology, 291:87-99. doi:10.1111/jzo.12052

Pol, D. \& Powell, J.E. 2011. A new sebecid mesoeucrocodylian from the Rio Loro Formation (Palaeocene) of north-western Argentina. Zoological Journal of the Linnean Society, 163:S7S36. doi:10.1111/j.1096-3642.2011.00714.x

Price, L.I. 1964. Sobre o crânio de um grande crocodilídeo extinto do Alto de Rio Juruá, Estado do Acre. Anais da Academia Brasileira de Ciências, 56:59-66.

Riff, D. \& Aguilera, O. 2008. The world's largest gharials Gryposuchus: description of G. croizati n. sp. (Crocodylia, Gavialidae) from the Upper Miocene Urumaco Formation, Venezuela. Palaeontologische Zeitschrift, 82:178-195.

Riff, D.; Romano, P.S.R.; Oliveira, G.R. \& Aguilera, O.A. 2010. Neogene crocodile and turtle fauna in Northern South America. In: C. Hoorn \& F. Wesselingh (eds.) Amazonia, landscape and species evolution: a look into the past, Wiley-Blackwell, p. 259-280. doi:10.1002/9781444306408.ch16

Salas-Gismondi, R.; Antoine, P.O.; Baby, P.; Brusset, S.; Benammi, M.; Espurt, N.; De Franceschi, D.; Pujos, F.; Tejada, J. \& Urbina, 
M.2007. Middle Miocene Crocodiles from the Fitzcarrald Arch, Amazonian Peru.Cuadernos del Museo Geominero, 8:355-360. Salas-Gismondi, R.; Flynn, J.J.; Baby, P.; Tejada-Lara, J.V.; Claude, J. \& Antoine, P.-O. 2016. A new 13 Million year old gavialoid crocodylian from Proto-Amazonian mega-wetlands reveals parallel evolutionary trends in skull shape linked to longirostry. PLoS ONE, 11:e0152453. doi:10.1371/journal.pone.0152453

Salas-Gismondi, R.; Flynn, J.J.; Baby, P.; Tejada-Lara, J.V.; Wesselingh, F.P. \& Antoine, P.-O. 2015. A Miocene hyperdiverse crocodylian community reveals peculiar trophic dynamics in proto-Amazonian mega-wetlands. Proceedings of the Royal Society B, 282:20142490. doi:10.1098/rspb.2014.2490

Scheyer, T.M.; Aguilera, O.A.; Delfino, M.; Fortier, D.C.; Carlini, A.A.; Sánchez, R.; Carrillo-Briceño, J.D.; Quiroz, L. \& Sánchez-Villagra, M.R. 2013. Crocodylian diversity peak and extinction in the late Cenozoic of the northern Neotropics. Nature Communications, 4:1907. doi:10.1038/ncomms 2940

Scheyer, T.M. \& Delfino, M. 2016. The late Miocene caimanine fauna (Crocodylia: Alligatoroidea) of the Urumaco Formation, Venezuela. Palaeontologia Electronica, 19.3.48A. doi: $10.26879 / 657$

Scheyer, T.M. \& Moreno-Bernal, J.W. 2010. Fossil crocodylians from Venezuela in the context of South American faunas. In: M.R. Sánchez-Villagra; O.A. Aguilera \& A.A. Carlini (eds.) Urumaco and Venezuelan Palaeontology - The Fossil Record of the Northern Neotropics, Indiana University Press, p. 192-213.

Sereno, P.C. \& Larsson, H.C.E. 2009. Cretaceous crocodyliforms from the Sahara. ZooKeys, 28:1-143. doi:10.3897/zookeys.28.325

Sill, W. 1970. Nota preliminar sobre un nuevo gavial del Plioceno de Venezuela y una discusión de los gaviales Sudamericanos. Ameghiniana, 7:151-159.

Souza, R.G.; Cidade, G.M.; Campos, D.A. \& Riff, D. 2016. New crocodylian remains from the Solimões Formation (Lower Eocene-Pliocene), state of Acre, southwestern Brazilian Amazonia. Revista Brasileira de Paleontologia, 19:217-232. doi:10.4072/rbp.2016.2.06

Souza-Filho, J.P. 1987. Caiman brevirostris sp. nov., um novo Alligatoridae da Formação Solimões (Pleistoceno) do Estado do Acre, Brasil. In: CONGRESSO BRASILEIRO DE PALEONTOLOGIA, 10, 1987. Anais, Rio de Janeiro, p. 173-180.

Souza-Filho, J.P. 1991. Charactosuchus sansaoi, uma nova espécie de Crocodilidae (Crocodylia) do Neógeno do Estado o Acre, Brasil. In: CONGRESSO BRASILEIRO DE PALEONTOLOGIA, 12, 1991. Resumos, São Paulo, p. 36.

Souza-Filho, J.P. 1993. Ocorrência de Charactosuchus fieldsi e Charactosuchus n. sp. (Crocodilia, Crocodilidae) no Neógeno da Amazônia brasileira. Ameghiniana, 30:113.

Souza-Filho, J.P. \& Bocquentin-Villanueva, J.C. 1989. Brasilosuchus mendesi, n. g., n. sp., um novo representante da Família Gavialidae do Neógeno do Acre, Brasil. In: CONGRESSO BRASILEIRO DE PALEONTOLOGIA, 11, 1989. Anais, Curitiba, p. 457-463.

Souza-Filho, J.P.; Bocquentin, J. \& Silva, E.G. 1993. Novas interpretações do gênero Brasilosuchus (Crocodylia) do Neógeno do Estado do Acre, Brasil. In: CONGRESSO BRASILEIRO DE PALEONTOLOGIA, 13, 1993. Resumos, São Leopoldo, p. 130.

Souza-Filho, J.P. \& Guilherme, E. 2011a. Novo registro de Mourasuchus amazonensis Price, 1964, no Mioceno-Superior do Estado do Acre, Brasil. In: CONGRESSO BRASILEIRO DE PALEONTOLOGIA, 22, 2011. Anais, Natal, p. 656-659.
Souza-Filho, J.P. \& Guilherme, E. 2011b. Ampliacão da diagnose e primeiro registro de Mourasuchus arendsi (CrocodyliaNettosuchidae) no Neógeno da Formacão Solimões, Amazônia Sul-Ocidental. In: I.S. Carvalho (ed.) Paleontologia: Cenários de Vida, Interciência, p. 399-408.

Souza-Filho, J.P. \& Kischlat, E.1995. Novos registros de Mourasuchus Price, 1964 (Crocodylia, Nettosuchidae) Cenozoico do Estado do Acre, Brasil. In: CONGRESSO BRASILEIRO DE PALEONTOLOGIA, 14, 1995. Atas, Uberaba, p. 127.

Staton, M.A. 1988. Studies on the use of fats and carbohydrates in the diet of American alligators (Alligator mississipiensis). University of Georgia, Ph.D. Thesis, 302 p.

Stromer, E. 1925. Ergebnisse der Forschungsreisen Prof. E. Stromers in den Wüsten Ägyptens. II. Wirbeltier-Reste der BaharijeStufe (unterstes Cenoman). 7 Stomatosuchus inermis Stromer, ein schwach bezahnter Krokodilier und 8. Ein Skelettrest des Pristiden Onchopristis numidus Huag sp. Abhandlungen der Bayerischen Akademie der Wissenschaften. Mathematischnaturwissenschaftliche Abteilung, 30:1-22.

Stromer, E. 1933. Ergebnisse der Forschungsreisen Prof. E. Stromers in den Würsten Ägyptens. II. Wirbeltierreste der BaharijeStufe (unterstes Cenoman), 12; die procoelen Crocodilia. Abhandlungen der Bayerischen Akademie der Wissenschaften. Mathematisch-naturwissenschaftliche Abteilung, 15:1-55.

Tineo, D.E.; Bona, P.; Pérez, L.M.; Vergani, G.D.; González, G.; Poiré, D.G.; Gasparini, Z.N. \& Legarreta, P. 2014. Palaeoenvironmental implications of the giant crocodylian Mourasuchus (Alligatoridae, Caimaninae) in the Yecua Formation (late Miocene) of Bolivia. Alcheringa, 39:224-235. doi:10.1080/03115518.2015.967162

Vanzolini, P.E. \& Gomes, N. 1979. Notes on the ecology and growth of Amazonian caimans (Crocodylia, Alligatoridae). Papeis Avulsos de Zoologia, 32:205-216.

Walmsley, C.W.; Smits, P.D.; Quayle, M.R.; McCurry, M.R.; Richards, H.S.; Oldfield, C.C.; Wroe, S.; Clausen, P.D. \& McHenry, C.R. 2013. Why the long face? The mechanics of mandibular symphysis proportions in crocodiles. PLoS ONE, 8:e53873. doi:10.1371/journal.pone.0053873

Wesselingh, F.P. 2006. Evolutionary ecology of the Pachydontinae (Bivalvia, Corbulidae) in the Pebas lake/wetland system (Miocene, western Amazonia). Scripta Geologica, 133:395-417.

Wesselingh, F.P.; Räsänen, M.E.; Irion, G.; Vonhof, H.B.; Kaandorp, R.; Renema, W.; Romero-Pittman, L. \& Gingras, M. 2002. Lake Pebas: a palaeoecological reconstruction of a Miocene, long-lived lake complex in western Amazonia. Cainozoic Research, 1:35-81.

Wu, X.C.; Sues, H.D. \& Sun, A. 1995. A plant-eating crocodyliform reptile from the Cretaceous of China. Nature, 376:678-680. doi:10.1038/376678a0

Received in 16 August, 2018; accepted in 30 May, 2019. 